\title{
Analisis Wacana Islam dalam Koran Jepang Ito Shinbun
}

\author{
${ }^{1}$ Febri Wibisono, ${ }^{1}$ Millitania Dienul Haq, ${ }^{1 *}$ Rafif Alhudaibi Walfajri, \\ ${ }^{1}$ Ikromah Febrianti, ${ }^{1}$ Millatuz Zakiah \\ ${ }^{1}$ Fakultas Ilmu Budaya, Universitas Brawijaya, Malang, Jawa Timur, Indonesia
}

\begin{abstract}
Mass media is a source of information, one of which is information about religion, including Islam. This study aims to examine how issues about Islam are represented in Japan through the mass media Ito Shinbun. This study uses a descriptive research method with a qualitative approach. The data were collected from articles in the digital version of Ito Shinbun newspaper. Based on the research results it was found that Ito Shinbun represented or reported issues related to Islam in a neutral way. In addition, it is also found that Islamic beliefs are written in Ito Shinbun's news which includes the concept of rejection of LGBT, law and sharia, halal food, and Islamic teachings that do not discriminate against humans.
\end{abstract}

Keywords: Representation, Islam, Critical Discourse Analysis, Ito Shinbun

\section{Pendahuluan}

Islamofobia adalah istilah kontroversial yang merujuk pada prasangka, diskriminasi, ketakutan dan kebencian terhadap segala sesuatu tentang Islam yang saat ini mewabah di negara-negara barat seperti di Amerika dan Eropa. Islamofobia diperkuat dengan kejadian-kejadian teror yang menggemparkan dunia, seperti serangan pada menara kembar World Trade Center (WTC) di New York City, Amerika Serikat pada 9 September 2001 oleh Osama Bin Laden (National Geographic.grid.id, 2018:1). Dampak dari Islamofobia masih terasa hingga kini, seperti pemeriksaan ekstra ketat di setiap imigrasi umat Islam yang berasal dari negara mayoritas Islam di Amerika (Republika.co.id, 2018:1), penuduhan

\footnotetext{
* Corresponding author: Rafif Alhudaibi Walfajri rafifalhudaibi@student.ub.ac.id

Published online at http://Islamicinsights.ub.ac.id/

Copyright $(\subset 2020$ PSP2M UB Publishing. All Rights Reserved
}

bulan ramadan akan memperparah virus corona karena umat Islam setempat banyak mengadakan kerumunan dan diskriminasi terhadap pelaksanaan ibadah umat muslim termasuk pendirian tempat ibadah di Inggris (Tirto.id, 2019:2) serta larangan memakai cadar di Prancis (Tempo.co, 2018:1). Hal ini tentunya sangat merugikan umat muslim.

Dikutip juga dalam tirto.id bahwa lebih dari sepertiga orang inggris percaya bahwa Islam adalah ancaman bagi kehidupan mereka. Kabar mencemaskan itu berasal dari laporan tahunan berjudul State of Hate dan mengutip The Guardian, laporan yang disusun sejak Juli tahun lalu itu menunjukan 35\% orang Inggris percaya Islam bisa menjadi ancaman dalam cara hidup orang Inggris. Sedangkan 32\% responden berpikir ada daerah terlarang di Inggris, tempat hukum syariah mendominasi dan nonmuslim tidak bisa masuk. Pada laporan 
terpisah yang dibuat pada Agustus 2018, sebanyak 30\% responden mendukung penolakan pembangunan masjid bahkan $21 \%$ berkata mereka tetap akan mendukung penolakan ini meski nantinya ada tindakan keras.

Berbeda dengan di Jepang, yang pada masa kini menjadi salah satu negara tujuan pendidikan, usaha, dan wisata yang populer. Banyaknya pelajar, pekerja, dan wisatawan muslim turut mempengaruhi perkembangan Islam di Jepang. Minister Sato, Wakil Duta Besar untuk Indonesia menyatakan bahwa di Jepang pada tahun 1930-an hanya ada dua masjid, namun saat ini sudah terdapat lebih dari seratus masjid. Masyarakat Islam yang ada di Jepang, paling banyak orang Indonesia, kemudian orang Pakistan, Bangladesh, dan Iran. Pusat Islam dan Asosiasi Muslim Jepang di Tokyo menjadi pusat studi Islam dan Bahasa Arab bagi warga Jepang, yang banyak menarik perhatian warga muda Jepang. Bandara-bandara internasional di Jepang pun berusaha menjadi lebih ramah kepada umat Islam dengan menyediakan fasilitas dan ruang ibadah di tengah kenaikan tajam pengunjung dari dunia Islam menyusul kelonggaran dari pemerintah Jepang tentang peraturan untuk mengeluarkan visa pada Juli 2013 Begitupun restoran atau produk makanan yang berlogo Halal mulai banyak bermunculan di berbagai wilayah negeri Sakura ini (Dunia.tempo.co., 2018:1). Hal ini tentu tidak lepas dari bagaimana cara media massa di Jepang menuliskan pemberitaan tentang Islam. Seorang penceramah internasional muslim dari India, Dr. Zakir Naik, mengungkapkan pentingnya peran media dalam menghadapi wabah Islamophobia yang menyelimuti dunia. Menurutnya, senjata terhebat di dunia saat ini adalah media yang bisa mengontrol opini masyarakat. Pada media massa dapat terlihat praktik kekuasaan dalam analisis wacana. Analisis wacana kritis (Critical Discourse Analysis) merupakan suatu bentuk analisis wacana yang salah satu kajiannya menganalisis praktik kekuasaan. Konsep kekuasaan di sini ialah alat yang dipakai untuk mengontrol sesuatu, dalam hal ini berbentuk wacana yang terhubung dengan masyarakat. Hal ini berarti suatu wacana bisa merupakan bentuk praktik kekuasaan di tengah-tengah masyarakat.

Van Dijk (1977:2) mengatakan bahwa media bersifat membujuk dan mempengaruhi karena media berpotensi mengontrol pikiran pembaca atau penonton walaupun tidak secara langsung mengontrol tindakan mereka. Setiap media memiliki gaya tersendiri saat memberitakan suatu hal, terutama pemberitaan terkait suatu agama tertentu.

Di Jepang terdapat media massa yang cukup berpengaruh yaitu Ito Shinbun. Sebagai salah satu surat kabar terbesar di Jepang tentunya artikel dalam Ito Shinbun banyak dibaca dan menjadi sumber pengetahuan maupun referensi bagi masyarakat Jepang, khususnya pemberitaan mengenai Islam. Data yang digunakan dalam penelitian ini merupakan artikel yang ada di dalam media massa online Ito Shinbun. Adapun pemilihan media massa online dikarenakan karena saat ini media massa online merupakan media yang sangat digemari karena berita yang didapatkan lebih cepat diakses oleh para pembacanya. Sementara media Ito Shinbun yang berasal dari Jepang dipilih untuk melihat bagaimana isu-isu mengenai Islam direpresentasikan di Jepang.

Dalam penelitian ini, peneliti ingin melihat seperti apa media massa Ito Shinbun dalam memberitakan isu-isu mengenai Islam di Jepang dan bagaimana 
pandangan orang Jepang terhadap Islam serta keyakinan Islam yang terkandung dalam pemberitaan tersebut apakah sesuai atau melenceng dari pandangan Islam yang sebenarnya.

Melihat antusiasme Jepang terhadap Islam di tengah ketakutan akan Islam (Islamophobia) yang sedang marak di belahan dunia barat seperti negaranegara di Eropa dan Amerika Serikat, tentu menimbulkan pertanyaan tersendiri. Seperti apakah representasi agama Islam di Jepang, terutama yang dituliskan oleh media cetak disana. Kenyataan ini membawa pertanyaan yang cukup menarik yang peneliti rumuskan sebagai berikut:

1. Bagaimana Islam direpresentasikan dalam artikel media massa Jepang Ito Shinbun?

2. Bagaimana pandangan yang mendasari pemberitaan mengenai Islam dalam media massa Jepang Ito Shinbun?

\section{Kerangka teori}

Wacana adalah suatu upaya pengungkapan maksud tersembunyi dari seorang subyek yang mengemukakan suatu pernyataan. Pengungkapan itu dilakukan diantaranya dengan menempatkan diri pada posisi seorang pembicara dengan penafsiran mengikuti struktur makna dari seorang pembicara.

Sedangkan analisis wacana yang dimaksudkan disini adalah untuk menggambarkan tata aturan kalimat, bahasa, dan pengertian bersama. Setelah melihat pengertian wacana yang ada di atas, maka dapat dikatakan bahwa analisis wacana adalah menelaah mengenai aneka fungsi (pragmatik) bahasa.

Menurut pandangan dari Eriyanto (2006:18) analisis wacana adalah merupakan salah satu kajian yang meneliti atau menganalisa bahasa yang digunakan secara alamiah, baik dalam bentuk lisan maupun tulisan. Eriyanto juga mengatakan bahwa analisis wacana menekankan kajian penggunaan dalam konteks sosial, khusunya dalam interaksi antar penutur. Selain itu, Eriyanto juga berpendapat bahwa analisis wacana merupakan kajian yang membahas tentang wacana, dan sedangkan wacana merupakan bahasa yang digunakan berkomunikasi.

Menurut Fairclough (2005:18), analisis wacana kritis melihat wacana dari pemakaian bahasa dalam tuturan dan tulisan sebagai bentuk praktik sosial. Menggambarkan wacana sebagai praktik sosial menyebabkan sebuah hubungan dialektis di antara peristiwa diskursif tertentu dengan situasi, institusi, dan struktur sosial yang membentuknya.

Fairclough (1995:17), analisis wacana kritis memusatkan analisis wacana pada bahasa dan menghubungkannya dengan ideologi. Analisis bahasa kritis lebih kongkret melihat gramatika. Inti dari gagasan Critical Linguistics adalah melihat bagaimana gramatika bahasa membawa posisi dan makna ideologi tertentu. dengan kata lain, aspek ideologi itu diamati dengan melihat pilihan bahsa dan struktur tata bahasa yang dipakai. Bahasa baik dari pilihan kata maupun struktur gramatika, dipahami sebagai pilihan, mana yang dipilih untuk diungkapkan membawa makna ideologi tertentu. Bahasa adalah suatu sistem kategorisasi dimana kosakata tertentu dapat dipilih yang akan menyebabkan makna tertentu.

Pendekatan Kognisi Sosial (Socio Cognitive Approach) Teun A Van Dijk memberi perhatian pada masalah etnis, dan pengungsi. Pendekatan ini disebut 
dengan kognisi sosial karena melihat faktor kognisi sebagai elemen penting dalam produksi wacana. Wacana bukan hanya dari struktur wacana, tetapi juga menyertakan suatu proses yang disebut dengan kognisi sosial.

Dari analisis teks misalnya dapat diketahui bahwa wacana cenderung memarjinalkan kelompok minoritas dalam pembicaraan publik. Tetapi menurut Van Djik, wacana seperti ini hanya tumbuh dalam suasana kognisi pembuat teks yang memang berpandangan cenderung memarjinalkan kelompok minoritas. Oleh karena itu, dengan melakukan penelitian yang komprehensif mengenai kognisi sosial akan dapat dilihat sejauh mana keterkaitan tersebut, sehingga wacana dapat dilihat lebih utuh.

\section{Pembahasan}

\subsection{Representasi Islam dalam Ito Shinbun}

Data-data yang telah peneliti kumpulkan akan dideskripsikan pada bagian ini. Adapun data mengenai juduljudul berita yang dipilih yaitu sebagai berikut:

1. Chinese official: China educating, not mistreating, Muslims

2. Islamist protesters clash with Pakistan police for 2 nd day

3. Malaysia cannot accept same-sex marriage, LGBT rights, says Mahathir

4. Muslims feel 'safe' cooking, eating halal ramen in Kyoto

Data yang peneliti analisis pertama adalah teks berita yang berjudul "Muslims feel 'safe' cooking, eating halal ramen in Kyoto" yang diambil dari surat kabar harian Jepang Ito Shinbun versi digital. Teks berita "Muslims feel 'safe' cooking, eating halal ramen in Kyoto" yang diterbitkan Ito Shinbun ini terdiri atas sebuah judul (headline) dan isi teks sebanyak tujuh paragraf yang mengangkat tema kuliner. Dalam teks berita tersebut direpresentasikan seorang karyawan muslim yang bekerja di restoran ramen sangat ramah terhadap karyawan lainnya dan restorannya pun sangat toleran terhadap pelanggan muslim bahkan memperbolehkan memasak makanan mereka sendiri menggunakan bahan-bahan halal dengan bantuan staff. Setelah kami analisis keseluruhan teksnya ditemukan kalimat yang merepresentasikan Islam secara positif sebanyak tujuh kalimat, secara netral sebanyak dua kalimat dan secara negatif tidak ada.

Data kedua yaitu teks berita yang berjudul "Islamist protesters clash with Pakistan police for 2nd day" yang juga diambil dari surat kabar harian Jepang Ito Shinbun versi digital dan terdiri sebuah judul (headline) dan isi teks sebanyak dua paragraf. Dalam berita tersebut direpresentasikan pengunjuk rasa Islam bentrok dengan polisi Pakistan. Pada paragraf pertama yang ditekankan yaitu Islam digambarkan dengan anarkis seperti pada teks "The protesters burned a car, three motorcycles and a guard post and then withdrew to a protest camp they have occupied for over two weeks" dan "According to reports, yesterday's clashes left six dead and dozens wounded". Pada kedua teks tersebut terlihat bahwa Islam digambarkan secara brutal.

Pada paragraf kedua dijelaskan kenapa para pengunjuk rasa Islam melakukan aksi yang anarkis seperti yang dijelaskan pada teks berikut "The demonstrators are demanding the resignation of Pakistan law minister Zahid Hamid because of an omitted reference to the Prophet Muhammad in 
a parliamentary bill". Dalam teks berita tersebut kalimat yang merepresentasikan Islam secara positif tidak ada, secara netral sebanyak satu kalimat dan secara negatif sebanyak empat kalimat walaupun digambarkan secara negatif namun juga dijelaskan alasannya. Dalam keseluruhan teks berita tersebut Islam direpresentasikan secara netral.

Data ketiga yaitu teks berita yang berjudul "Malaysia cannot accept samesex marriage, LGBT rights, says Mahathir" terdiri dari sebuah judul (headline) dan isi teks sebanyak delapan paragraf dengan topik penolakan lesbian, gay, biseksual dan transgender (LGBT) oleh muslim di Malaysia. Dalam teks berita tersebut Islam direpresentasikan dengan tegas menolak LGBT karena bertentangan dengan hukum atau syariat Islam. Perdana Mentri Mahathir juga mengatakan dengan tegas kepada wartawan "In Malaysia there are some things we cannot accept, even though it is seen as human rights in Western countries. We cannot accept LGBT, marriage between men and men, women and women". Bahkan dua wanita dicambuk karena mencoba seks lesbian dan sebuah bar gay di Kuala Lumpur digerebek oleh polisi dan petugas penegak agama, sementara seorang wanita transgender dipukuli oleh sekelompok penyerang di Seremban. Dalam teks tersebut kalimat yang merepresentasikan Islam secara positif sebanyak lima kalimat, secara netral sebanyak satu kalimat dan secara negatif sebanyak satu kalimat. Keseluruhan teks berita tersebut Malaysia menggambarkan seks oral dan anal bertentangan dengan hukum Islam dan Hukum Perdata menetapkan penjara hingga 20 tahun, cambuk dan denda bagi pelanggar.

Data keempat yaitu teks berita yang berjudul "Chinese official: China educating, not mistreating, Muslims" terdiri dari sebuah judul (headline) dan isi teks sebanyak sembilan paragraf. Dalam teks berita tersebut Islam direpresentasikan masih dipandang dengan baik di China tetapi mereka menempatkan beberapa orang muslim melalui pelatihan khusus untuk menangani penyebaran ekstrimisme Islam yang telah memicu kecaman internasional dengan tuduhan pelanggaran hak asasi manusia bahkan menolak gagasan untuk meminta seorang ahli PBB mengunjungi pelatihan khusus tersebut, dengan mengatakan tidak perlu mereka menganggap Islam adalah hal yang baik dalam pandangan China tetapi ekstrimisme Islam adalah musuh bersama umat manusia seperti yang terlihat di Afghanistan, Suriah, Pakistan, Iraq dan banyak negara lainnya. Dalam teks tersebut Islam direpresentasikan secara positif sebanyak satu kalimat, secara netral sebanyak dua kalimat dan secara negatif sebanyak empat kalimat. Secara keseluruhan representasi Islam dalam teks berita tersebut negatif.

\section{4.2 PandanganPencitraan yang Mendasari Pemberitaan Mengenai Islam Dalam Ito Shinbun}

Data pertama yang berjudul "Muslims feel 'safe' cooking, eating halal ramen in Kyoto" direpresentasikan cenderung lebih banyak menggunakan kalimat pasif dengan subyek ramen halal untuk memberikan citraan positif bahwa umat muslim tidak perlu khawatir lagi tentang makanan halal khususnya di daerah Kyoto. Wartawan yang memberitakan juga menggunakan bahasa yang sederhana dan mudah dimengerti serta dekat dengan percakapan seharihari. Hal demikianlah yang membuat pembaca tertarik yang notabene adalah umat muslim di Jepang. 
Data kedua yang berjudul "Islamist protesters clash with Pakistan police for 2nd day" direpresentasikan cenderung lebih banyak menggunakan kalimat aktif dengan subyek pengunjuk rasa Islam untuk memberikan citraan negatif bahwa para pengunjuk rasa Islam adalah sekelompok orang yang anarkis dan brutal. Wartawan yang memberitakan juga menekankan pada pengunjuk rasa yang merusak fasilitas umum seperti membakar sebuah mobil tiga sepeda motor dan satu pos penjagaan.

Data ketiga yang berjudul "Malaysia cannot accept same-sex marriage, LGBT rights, says Mahathir" direpresentasikan dengan gaya bahasa yang bersifat tegas dan banyak menggunakan kalimat aktif yang berisi hukuman dan penolakan terhadap LGBT. Wartawan yang memberitakan juga menggunakan bentuk yang bersifat mengajak para pembacanya untuk menghindari LGBT dan juga mewawancarai Perdana Mentri Malaysia Mahathir Mohamad yang komentarnya kemungkinan akan memicu perdebatan lebih lanjut di mana para aktivis telah menyuarakan keprihatinan atas permusuhan terhadap kelompok LGBT baik dari dalam masyarakat maupun dari pemerintah.

Data keempat yang berjudul Chinese official: China educating, not mistreating, Muslims" direpresentasikan cenderung lebih banyak menggunakan kalimat aktif dengan subyek ekstrimisme muslim untuk memberikan citraan negatif kepada seluruh dunia dalam pertemuan PBB yang dimana Islam adalah hal yang baik dalam pandangan China namun tidak dengan ekstrimisme Islam, mereka adalah elemen yang sangat buruk seperti yang terlihat di negaranegara timur tengah seperti Afganistan, Suriah, Pakistan, Iraq dan banyak negara lainnya.

\section{Simpulan}

Penelitian ini mengeksplorasi representasi agama Islam dalam pemberitaan di media massa. Secara spesifik, penelitian ini mengkaji dua permasalahan, yakni Bagaimana Islam direpresentasikan dalam artikel media massa Jepang Ito Shinbun dan Bagaimana pandangan yang mendasari pemberitaan mengenai Islam dalam media massa Jepang Ito Shinbun

Berdasarkan hasil analisis yang telah dipaparkan pada pembahasan sebelumnya, ditemukan bahwa Ito Shinbun merepresentasikan Islam secara positif sebanyak 13 kalimat (46\%), secara netral sebanyak 6 kalimat $(21 \%)$ dan secara negatif sebanyak 9 kalimat (33\%). Secara pandangan dapat dilihat upaya Ito Shinbun untuk bersikap netral dalam memberitakan isu-isu yang berkaitan dengan Islam. Adapun dalam pemberitaannya terkandung beberapa keyakinan Islam yang mencakup konsep penolakan terhadap LGBT, , hukum dan syariat, makanan halal, dan ajaran Islam yang tidak membeda-bedakan manusia.

$\begin{array}{ccc}\text { Untuk saran, } & \text { peneliti } \\ \text { merekomendasikan untuk meneliti }\end{array}$ bagaimana proses penerjemahan artikel dari Ito Shinbun versi bahasa Jepang ke dalam versi bahasa Inggris. Sebagai contoh, artikel berjudul Muslims feel 'safe' cooking, eating halal ramen in Kyoto memiliki judul asli dalam bahasa Jepang 京都) 作ろう「ハラル」ラー メン東山に体験型店舗開店 Judul ini apabila diterjemahkan ke dalam bahasa Indonesia akan menjadi sebuah kalimat yang berarti "Ayo coba membuat ramen halal di Higashiyama, Kyoto". Hal ini tentu jauh berbeda dengan judul artikel dalam bahasa Inggris yang apabila diterjemahkan ke dalam bahasa Indonesia berarti “Muslim merasa 'aman' 
memasak dan memakan ramen halal di Kyoto". Proses penerjemahan ini menarik untuk diteliti lebih lanjut.

\section{Referensi}

Eriyanto. (2006). Analisis Wacana

Pengantar Analisis Teks Media.

LKIS: Yogyakarta.

Valid Consulting. (2012). Diakses dari https://validconsulting.wordpres s.com $/ 2012 / 11 / 27 /$ kerangkaanalisis-wacana

Fairclough, Norman. (2005). Analysing Discourse Textual: analysis for social research. Routledge: London and New York.

Fairclough, Norman. (1995). Critical Discourse Analysis: The Critical of Language. Longman: London and New York.

Firmansyah, Teguh. (2018). Kebijakan Trump dan Kebangkitan Politik. Muslim AS. Diakses dari https://m.republika.co.id/berita /phgpla377.html

Irfani, Faisal. (2019). Saat Inggris Harus Berjuang Mengatasi Islamofobia. Diakses dari https://tirto.id.html

Laras, Gita. (2018). Kronologis Serangan 9/11: Runtubnya Menara Kembar dan Osama bin Laden. Diakses dari www.nationalgeographic.grid.id/r ead.html

Sekarwati, Suci. (2018). Larangan Pakai Cadar di Prancis Melanggar HAM.

Diakses dari https://dunia.tempo.co/read/11 39291.html

Supratman, Agung. (2018). Islam di Jepang. Diakses dari https://dunia.tempo.co/read/17 34251.html
Teun, Van Dijk. (1977). Text and Conext (Explorations in the Semantics and Pragmatics of Discourse). New York: Longman London and New York. 